\title{
THE INFLUENCE OF FINE FRACTIONS CONTENT IN NON-COHESIVE SOILS ON THEIR COMPACTIBILITY AND THE CBR VALUE
}

\author{
Aleksandra BĄK(1D*, Ryszard CHMIELEWSKI(10) \\ Civil Engineering and Geodesy Faculty, Military University of Technology, Warsaw, Poland
}

Received 30 November 2018; accepted 26 February 2019

\begin{abstract}
The bearing capacity of subsoils is particularly important due to the intensive development of road and airfield pavements. Subgrade is classified due to frost susceptibility as non-frost-susceptible, low-frost-susceptible or frost-susceptible. Presented research included laboratory tests of low-frost-susceptible soils with limited potential for direct use. The main objective of this paper was focused on the study of changes of compactibility parameters and the CBR (Californian Bearing Ratio) values of silty sand $(\mathrm{P} \pi)$. For this purpose, seventeen soil samples with various fine fractions content (of $1.6 \%$ to $24.2 \%$ ), were composed. Laboratory tests, based on soaked soil samples, encompassed the Proctor Compaction test and the CBR test. Additionally, measurements of moisture content in soaked soil samples before and after the penetration test and the displacement of annular surcharge rings while penetration test, were performed. Obtained results allowed for conclusions that penetration curves diverge from the standard curve locally, therefore direct reading of the CBR values from the penetration curves may lead to its significant overstatement. There was also noticed the dependence between the water flow in the soil and the fine fraction content. The research recognized the need for pressure measurement in soil samples during the penetration test.
\end{abstract}

Keywords: non-cohesive soil, fine fraction, optimum moisture content (OMC), maximum dry density (MDD), CBR test, soaked soil, compactibility parameters, subgrade, frost susceptibility.

\section{Introduction}

Due to the development of road infrastructure in Poland planned communication routes often pass through areas, where subgrade has limited potential for direct use. One of commonly used test to determine the bearing capacity of the subgrade for road and airfield pavements is the Californian Bearing Ratio (CBR). Mentioned test was created in the United States Army Corps of Engineers and its development continues to this day, as evidenced by the new research programs concerning the CBR test (Gonzalez, Barker, \& Bianchini, 2012; Kodikara, Islam, \& Sountharajah, 2018). The CBR test was previously used to determine the bearing capacity of the road subgrade in the USA (ASTM International, 2007); however it was applied to the canon of research in Poland in slightly modified form. The scope of adaptation of the CBR method to national conditions is specified in the PN-S-02205:1998 standard (Polski Komitet Normalizacyjny, 1998). The designers in Poland often use the Catalogue of Typical Flexible and Semi-rigid Pavements for the dimensioning of road pavement structures (Generalny Dyrektor Dróg
Krajowych, 2014; Rozporządzenie Ministra Transportu i Gospodarki Morskiej, 1999). According to the Catalogue the dimensioning and the selection of the corresponding pavement structure of flexible and semi-rigid pavements is based on the calculation algorithm that takes into account ground and water conditions and traffic classification (Chmielewski \& Waliszewski, 2016).

The Catalogue (Generalny Dyrektor Dróg Krajowych, 2014) defines four different subgrade bearing capacity groups: from G1 (load-bearing subgrade) to G4 (nonload-bearing subgrade). Mentioned groups depend on water conditions, type of soil underneath the construction layers and load bearing capacity parameters based on the CBR value. Classification of the water conditions of the subgrade of the pavement structure is based on determination of the road body characteristics (excavation/embankment), type of shoulders (hardened/unpaved) and the level of the groundwater table. Subgrade soil is classified due to frost susceptibility (non-frost-susceptible, low-frostsusceptible soil, frost-susceptible). If the subgrade, that is

*Corresponding author. E-mail: aleksandra.bak@wat.edu.pl 
made up of low-frost-susceptible soils is under unfavorable conditions, such as irrigation, snowmelts, etc., the soil can be non-load-bearing. In this case the CBR test should be always conducted. The final subgrade bearing capacity group should be assumed based on comparison of the group determined directly from the Californian Bearing Ratio test and the group evaluated according to the assessment of frost susceptibility of soil and water conditions. This comparison allows selecting a reliable group that is the lower of the compared ones (Chmielewski \& Waliszewski, 2016; ASTM International, 2007). Therefore, if the water conditions are good and the CBR value is greater than $10 \%$, it is possible to classify low-frost-susceptible soil into G1 group. On the other hand, if the CBR value is less than $10 \%$, the soil should by classified into G2 group or lower, which indicates the need to strengthen the "weak subgrade". Many authors point to the problem of performance period and life span of pavements, that result directly from the strength characteristics of the pavements, which are influenced by material properties (i.e. fine fraction content) (Osouli, Othmanawny, Tutumluer, Beshears, \& Shoup, 2018; Osouli, Chaulagai, Tutumuler, \& Shoup, 2019).

Presented research, as well as carried out laboratory tests, were focused on the study of changes of the compactibility parameters and CBR values of silty sand $(\mathrm{P} \pi)$, which according to the Catalogue (Generalny Dyrektor Dróg Krajowych, 2014) is classified as low-frost-susceptible soil.

\section{Materials and methods}

\subsection{Materials}

In the study, samples composed by mixing different soils were used. Mentioned mixing allowed to obtain soil samples with different content of fine fractions, understood as the sum of silty and clay fraction (with a diameter below $\left.0.063 \mathrm{~mm}, f_{\pi}+f_{i}\right)$. Specific gravity of all soil samples, that were composed, was $2.65 \mathrm{~g} / \mathrm{cm}^{3}$. Thereby, a wide range of non-cohesive soils with a fine fraction content of $1.6 \%$ to $24.2 \%$ were obtained. Similar approach was presented in other research (Pilegis, Gardner, \& Lark, 2016; Matsumura $\&$ Tatsuoka, 2018). The grain-size analysis was performed using the wet sieving method supported by the aerometric method that allowed supplementing the graining curve for fine fractions. The graining for each soil composition was tested both before and after the CBR test. The differences in the content of fine fractions below $0.1 \%$ were obtained. In Figure 1 average values of these measurements were presented. The tests were carried out on seventeen different soil samples. The course of grain curves of all composed soil samples was similar; therefore both values of coefficient of uniformity and coefficient of curvature for all soils amounted to about 3 and 1, respectively. To ensure readability of graphs, in the Figure 1 the grading curves of selected five samples are presented.

To improve identification of individual of the examined soils, the names assigned to them in further parts of the article, were related to the contents of fine fractions $f_{\pi}+f_{i}$.

\subsection{Methods}

The analysis for each soil was carried out for soaked samples in accordance to the Standards (Polski Komitet Normalizacyjny, 1998). All of composed soil samples were compacted using the standard Proctor compaction test. After preparation these samples were subject to four-day saturation in a soaking tank. Then according to mentioned Standards, the soil samples were subjected to the one point CBR test with $4.5 \mathrm{~kg}$ surcharge weight. The results of previously conducted studies are presented in paper (Chmielewski \& Waliszewski, 2016), as well as the results of researches of other authors (Bednarek \& Mazurek, 2011; Khillare, Damgir, \& Hake, 2016; Fattah, Joni, \& AlDulaimy, 2016; Hossain, Islam, \& Rakib, 2016; Thakur \&

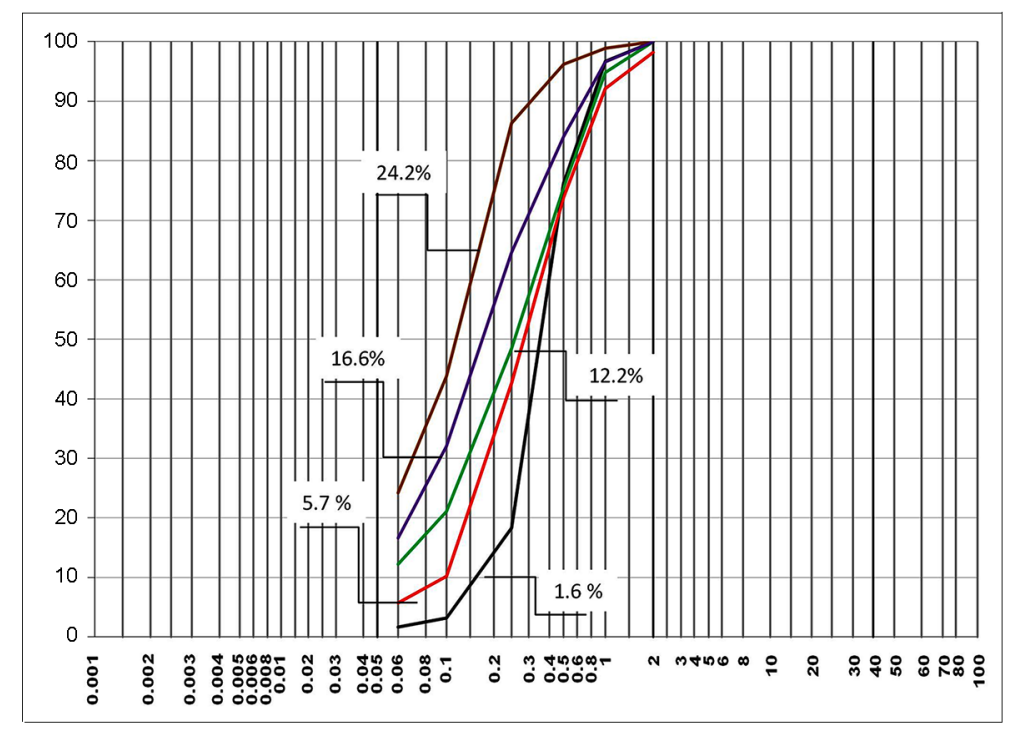

Figure 1. The grading curves of selected soils 


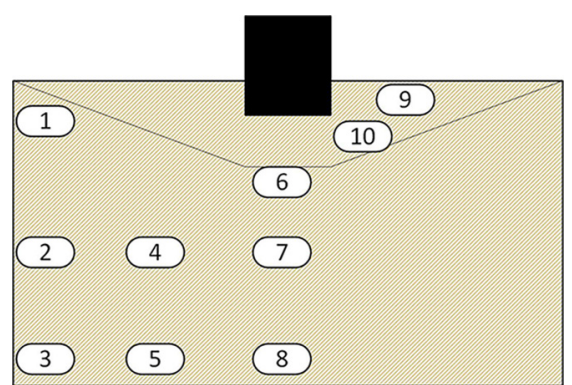

Figure 2. The distribution of moisture measurement points in the cross-section of soil samples

Yadav, 2018) show that obtained penetration curves diverge from the standard curve locally. The results of these studies indicate that mentioned deviations occur most frequently for indentation close to reference penetration values which are 2.5 and $5.0 \mathrm{~mm}$. Direct reading of the CBR values from the penetration curves may lead to its significant overstatement, therefore it is necessary to correct them (Chmielewski \& Waliszewski, 2016; Bednarek \& Mazurek, 2011)

During the CBR test for each soil sample that differs in the fine fraction content measurements of additional features of tested soils were performed. One of them was measurements of moisture distribution in soaked soil samples before and after the penetration test. For this purpose, two samples were prepared, for each of tested soil. The distribution of measuring points in cross-section of the sample is shown in Figure 2.

Moisture measurements, that was made by the drying method, were performed on samples taken from the same points of cross-section (in further parts of the article assigned as $w_{1}-w_{10}$ - compare Figure 2), for all seventeen soil compositions. Proper distribution of the measurement points is crucial for the interpretation of the moisture changes. Therefore, the first three points (1-3) were located on the side of the soil samples, the next two (4-5) in the middle, between the side and the central axis of the sample. Points no. 6-8 were located in the central axis of the cross-section of the sample. The last two points (no. 9 and 10) were placed near to the top surface of the sample. The location of the last two measuring points is associated with a formation of truncated cone after the penetration test - see Figure 3.

The measurements of the displacement of the annular surcharge rings during the penetration test were another of established parameters. The location of the additional displacement sensor is shown in Figure 4.

The displacements of the annular surcharge rings were continuously measured during the penetration test.

\section{Results}

The compactibility parameters (MDD and OMC) were determined in the standard Proctor compaction test that according to the standard (Polski Komitet Normalizacyjny, 1998) was performed by method I (normal method). The

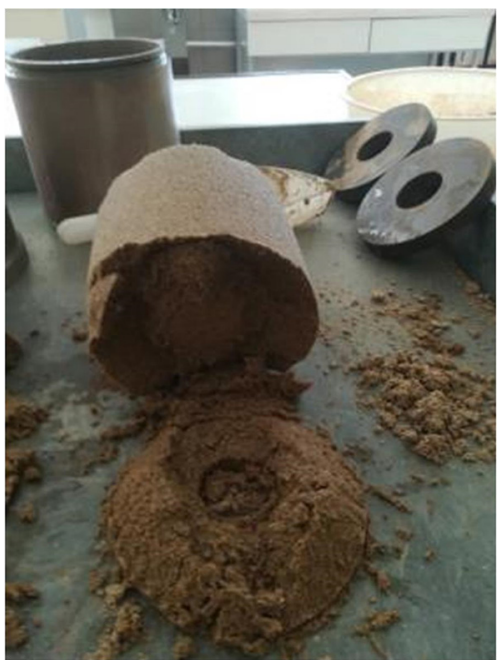

Figure 3. The view of the soil sample after the CBR test

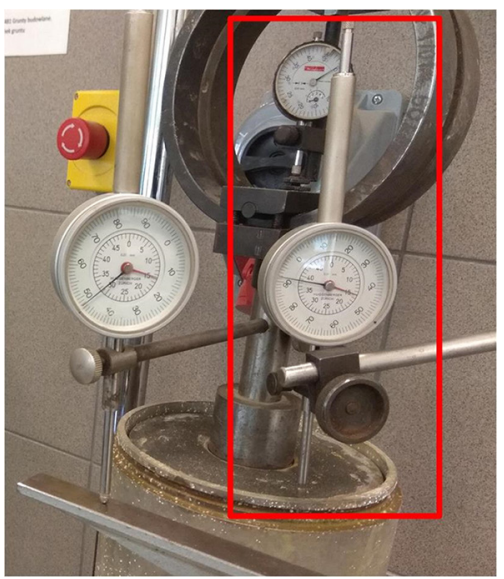

Figure 4. The location of the annular surcharge ring displacement sensor in the CBR loading press

following physical characteristics have been determined for all of tested soil samples:

- optimum moisture content (OMC);

- maximum dry density (MDD);

- porosity index (PI);

- moisture content of fully saturated soil $w_{\text {sat }}$;

- degree of saturation at the optimum moisture content $S_{\text {rwopt }}$.

The results are presented in Table 1.

Conducted research, as well as analysis performed by other authors, point to some regularities in changes of the compactibility parameters of tested soil samples (Sulewska \& Tymosiak, 2018; Gupta \& Thomas, 2013; Wright, Walden, Sangha, \& Langdon, 1996; Zhemchuzhnikov, Ghavami, \& Casagrande, 2016; Roy, 2013). Mentioned changes depending on the content of fines and sands in testes soil are clearly visible (Satyaveni, Sridevi, Sivanarayana, \& Prasad, 2018). The influence of the content of fine fraction on the performance of a soil is particularly emphasized (Cabalar \& Mustafa, 2017). The increase of the fine fraction content (on the following graphs, called as $f_{\pi}+f_{i}$ ) results 
Table 1 . The compactibility parameters of the tested soils

\begin{tabular}{|c|c|c|c|c|c|}
\hline $\begin{array}{c}f_{\pi}+f_{i} \\
(\%)\end{array}$ & $\begin{array}{c}\text { OMC } \\
(\%)\end{array}$ & $\begin{array}{c}\mathrm{MDD} \\
\left(\mathrm{g} / \mathrm{cm}^{3}\right)\end{array}$ & $\mathrm{PI}$ & $\begin{array}{c}w_{\text {sat }} \\
(\%)\end{array}$ & $S_{\text {rwopt }}$ \\
\hline 1.6 & 10.5 & 1.794 & 0.449 & 17.0 & 0.62 \\
\hline 2.9 & 9.7 & 1.797 & 0.447 & 16.9 & 0.58 \\
\hline 4.7 & 9.9 & 1.834 & 0.418 & 15.8 & 0.63 \\
\hline 5.2 & 10 & 1.85 & 0.405 & 15.3 & 0.65 \\
\hline 5.7 & 8.9 & 1.82 & 0.429 & 16.2 & 0.55 \\
\hline 6.2 & 9.7 & 1.774 & 0.466 & 17.6 & 0.55 \\
\hline 7.2 & 8.8 & 1.879 & 0.384 & 14.5 & 0.61 \\
\hline 8.3 & 9.3 & 1.813 & 0.434 & 16.4 & 0.57 \\
\hline 9.2 & 9 & 1.82 & 0.429 & 16.2 & 0.56 \\
\hline 12 & 8.2 & 1.892 & 0.374 & 14.1 & 0.58 \\
\hline 12.2 & 7.8 & 1.924 & 0.351 & 13.3 & 0.59 \\
\hline 13.5 & 8.5 & 1.916 & 0.357 & 13.5 & 0.63 \\
\hline 15.5 & 8.3 & 1.902 & 0.367 & 13.8 & 0.60 \\
\hline 16.6 & 8.9 & 1.876 & 0.386 & 14.6 & 0.61 \\
\hline 19.2 & 9.6 & 1.868 & 0.392 & 14.8 & 0.65 \\
\hline 20.5 & 9.6 & 1.855 & 0.402 & 15.2 & 0.63 \\
\hline 24.2 & 9.3 & 1.832 & 0.419 & 15.8 & 0.59 \\
\hline
\end{tabular}

in maximum dry density (MDD) enhancement, while the amount of water, needed to obtain optimum moisture content, decreases (Habasimibi \& Nishimura, 2018; Gadzama, Yohanna, Wadai, Nwaiwu, \& Malachy, 2018). Laboratory tests, that were carried out have shown that further enhancement of the content of fine fractions, when the maximum soil compaction have been reached, contribute to the increase of the amount of water in the soil sample, that is necessary to obtain the optimal moisture content (OMC), while the dry density decreases (MDD) - see Figures 5 and 6.

Non-linear dependence between the compactibility parameters (the maximum dry density and optimum moisture content), that were obtained in the Proctor Compaction and the fine fraction content was also confirmed by many papers regarding both natural and stabilized soils (Hossain et al., 2016; Sulewska \& Tymosiak, 2018; Gupta

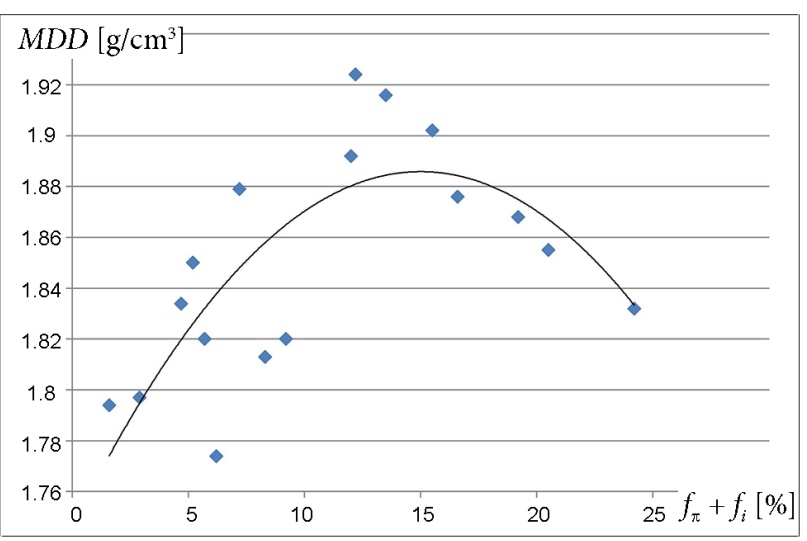

Figure 5. The dependence between the maximum dry density and the content of fine fractions

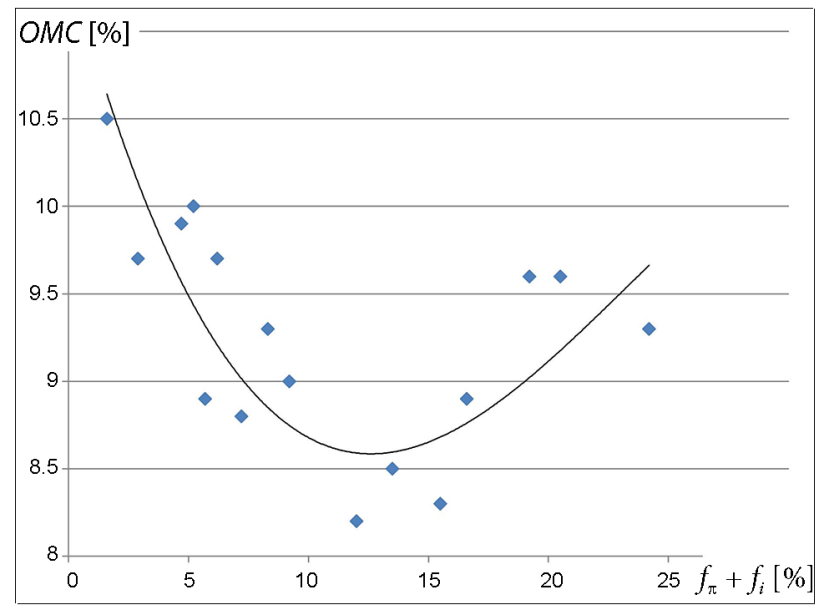

Figure 6. The dependence between optimum moisture content and the fine fractions content

\& Thomas, 2013; Wright et al., 1996; Zhemchuzhnikov et al., 2016; Osouli, Salam, Tutumluer, \& Shoup, 2017). This clear relationship developed between the compactibility parameters and the CBR value causes that numerous scientific studies attempt to predict the CBR value based on Maximum Dry Density (MDD), Optimum Moisture Content (OMC), the content of sand, clay or silt fractions (Sreelekshmypillai \& Vinod, 2017; Katte, Mfoyet, Manefouet, Wouatong, \& Bezeng, 2019).

The changes of soil compactibility depending on the content of fine fractions are shown in Figure 7.

Soil moisture measurements in the cross - section of the samples were performed with oven drying method, with a weighing accuracy to $0.01 \mathrm{~mm}$, that corresponds to the accuracy of determined moisture content of $0.05 \%$. In Table 2 the changes of the moisture content values in the soaked soil samples are presented. Mentioned changes were observed in points no. 2, 4 and 7 (compare to Figure 2) in the soil samples, that have not been subjected to the penetration test.

Based on the results of the measurements, regularities of the water flow patterns in the soil depending on the content of fine fraction were observed (Thakur \& Yadav, 2018; Habasimibi \& Nishimura, 2018; Yin, Zhang, Jiang, \& Huang, 2018; Salam, Osouli, \& Tutumluer, 2018). The first of analyzed dependences is the correlation between the increase of the moisture in the middle of the sample (moisture in measurement point no. $7, w_{7}$ ) and the optimum moisture content (OMC) for which the sample was compacted. Analysis of the results of optimum moisture content allowed distinguishing several characteristic groups of soils. The highest increase of the moisture content (about $2 \%$ ) was observed in case of soils with fine fraction content of about $6 \%$. The next group is made up of soils with the fine fraction content from $6 \%$ to $17 \%$, where the increase in moisture content is $0.5 \div 1.0 \%$. Soils with the highest content of fine fractions show a fairly distinct increasing tendency of the moisture content. Mentioned trend of the change in the moisture content is presented in Figure 8. 


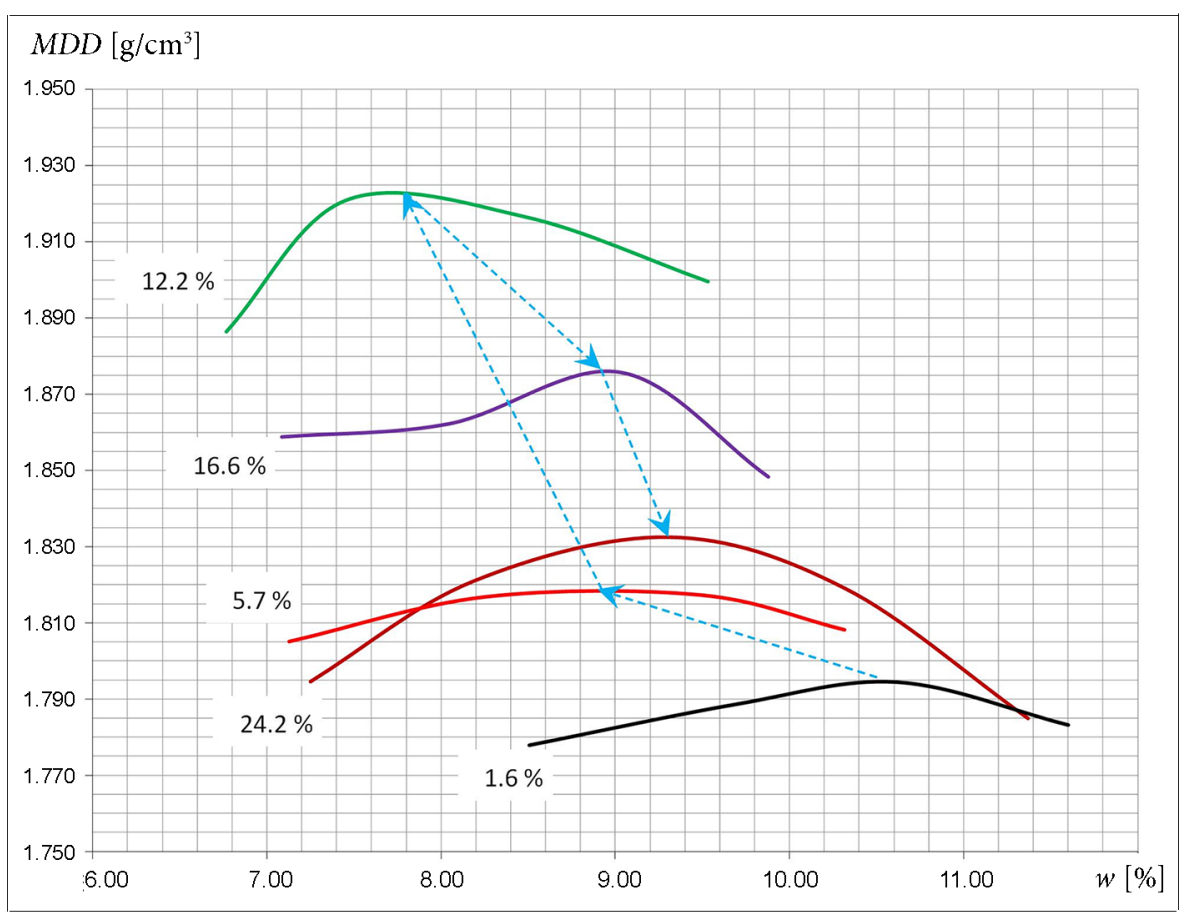

Figure 7. Changes of soil compactibility curves with different content of fine fractions

Table 2. The increase of the moisture content in the middle of the height of the soil samples untreated to the penetration test

\begin{tabular}{|c|c|c|c|c|}
\hline \multirow{2}{*}{$f_{\pi}+f_{i}$} & \multirow{2}{*}{$\begin{array}{c}\text { OMC } \\
w_{\text {opt }}\end{array}$} & $\begin{array}{c}\text { Measurement } \\
\text { point no. 2 }\end{array}$ & $\begin{array}{c}\text { Measurement } \\
\text { point no. 4 }\end{array}$ & $\begin{array}{c}\text { Measurement } \\
\text { point no. 7 }\end{array}$ \\
\hline 1.6 & 10.5 & 13.08 & 13.14 & 13.08 \\
\hline 2.9 & 9.7 & 12.21 & 11.55 & 11.6 \\
\hline 4.7 & 9.9 & 13.21 & 12.07 & 12.17 \\
\hline 5.2 & 10 & 12.12 & 11.88 & 12.08 \\
\hline 5.7 & 8.9 & 11.4 & 10.94 & 11.54 \\
\hline 6.2 & 9.7 & 12.73 & 12.82 & 11.9 \\
\hline 7.2 & 8.8 & 10.71 & 10.02 & 9.63 \\
\hline 8.3 & 9.3 & 10.3 & 10.19 & 10.1 \\
\hline 9.2 & 9 & 10.87 & 9.43 & 9.45 \\
\hline 12 & 8.2 & 9.88 & 9.44 & 9.33 \\
\hline 12.2 & 7.8 & 10.02 & 9.57 & 8.98 \\
\hline 13.5 & 8.5 & 10.32 & 9.32 & 9.12 \\
\hline 15.5 & 8.3 & 10.86 & 9.46 & 9.29 \\
\hline 16.6 & 8.9 & 11.35 & 10.27 & 9.54 \\
\hline 19.2 & 9.6 & 11.31 & 10.55 & 10.76 \\
\hline 20.5 & 9.6 & 11.9 & 10.6 & 10.84 \\
\hline 24.2 & 9.3 & 12.36 & 11.57 & 11.34 \\
\hline & & & & \\
\hline
\end{tabular}

Based on data presented on the graph (Figure 8), it can be noticed that the water flow in soil with average fine fractions content, is the most difficult (Yin et al., 2018). Analysis of the displacement of annular surcharge rings also allowed to define several regularities - up to the penetra-

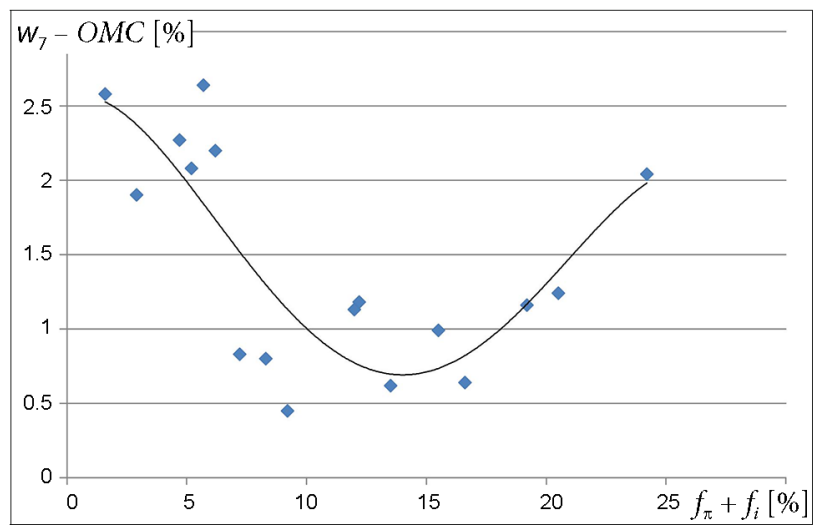

Figure 8. Increase of the moisture content as a function of the fine fraction content

tion depth of about $3.0 \mathrm{~mm}$, due to the densification of the testes soils, the annular surcharge rings moves downwards that proves the compacting of the soils. The dependence between the maximum value of subsidence $\left(v_{\text {down }}\right)$ and the fine fraction content is shown in Figure 9.

In case of soils with low fine fraction content, pressing the piston up to $2.5 \mathrm{~mm}$ results in displacements of annular surcharge rings with positive values, i.e. the annular surcharge rings are uplifted. Along with the increase of the fine fraction content the displacements $\left(v_{2,5}\right)$ are getting smaller, this leads to the conclusion that the phenomenon of soil densification proceed in larger penetration depth achieved during the CBR test - see Figure 10.

An approximation of the standard curve allowed to take into account a local increase in the CBR values on the measurement graph. The penetration test curve was 


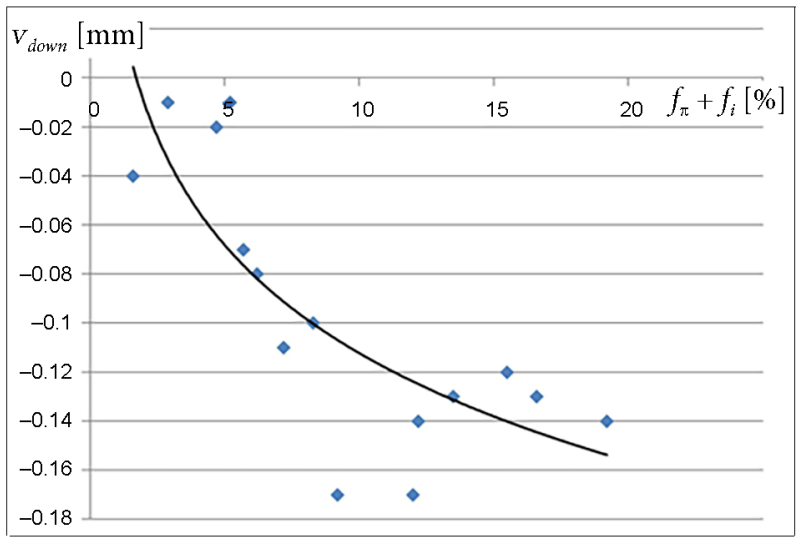

Figure 9. The dependence between maximum downward displacement of the annular surcharge rings and the content of fine fraction

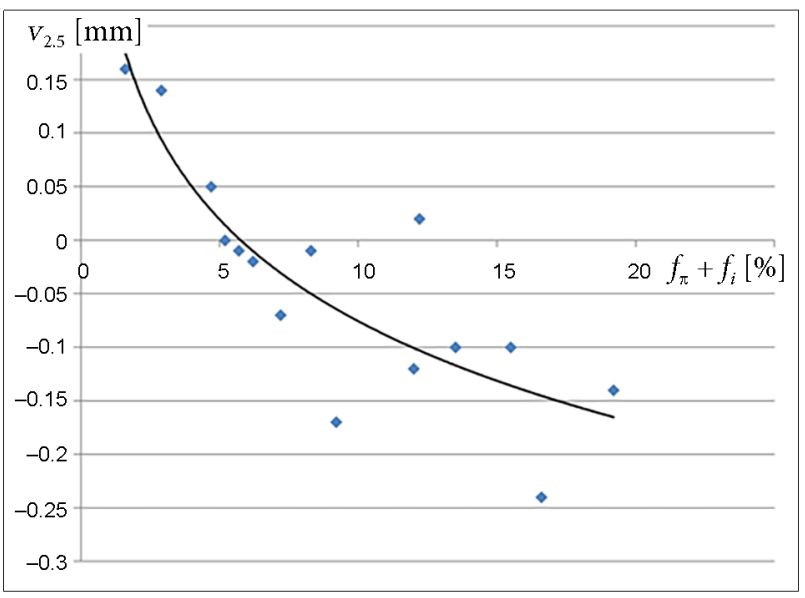

Figure 10. The dependence between annular surcharge rings displacement and the fine fraction content for penetration depth of $2.5 \mathrm{~mm}$

approximated by the fourth degree polynomial, for which the coefficient of determination for standard curve is $R^{2}=1$ (Chmielewski \& Waliszewski, 2016). An almost linear correlation between the fine fraction content and the CBR values can be noticed. This is particularly apparent for $C B R_{\text {cor }}$ (the corrected $C B R$ value) values, that have been corrected - see Figure 11.

The graph above shows the difference between the CBR values obtained from the measurements and corrected CBR values (in further parts of the paper called as $C B R_{\text {cor }}$ ). The smallest difference $(5.12 \%)$ was observed in case of soils with the fine fraction content of $5.7 \%\left(f_{\pi}+f_{\mathrm{i}}\right.$ $=5,7 \%)$ and the largest $-15.45 \%$ was observed for soils with the fine fraction of $12.0 \%$. The results of the CBR test are presented in Figure 12, where the measurement curves are marked with the blue line and the violet one presents graphs of corrected values. Similar curve shape (of uncorrected CBR values) was presented in many papers (Bednarek \& Mazurek, 2011; Khillare et al., 2016; Fattah et al., 2016; Hossain et al., 2016; Zhemchuzhnikov et al., 2016).

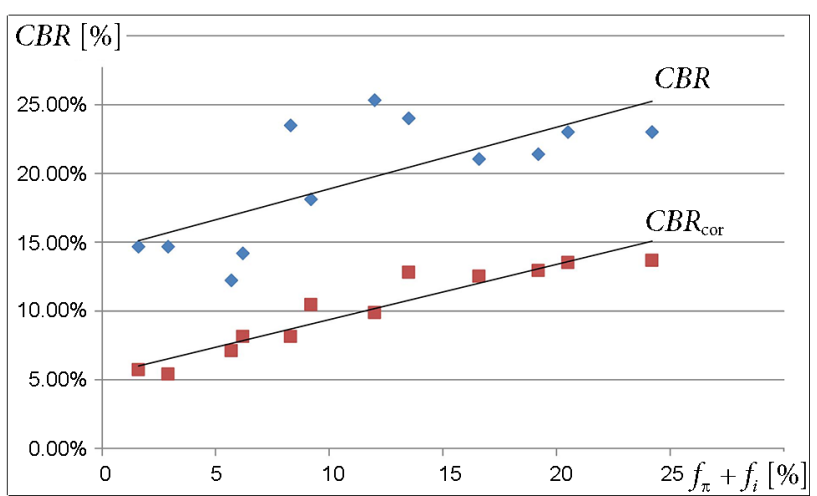

Figure 11. The dependence between the fine fraction content and the CBR value

\section{Discussion}

Figure 13 presents the trend lines of soil moisture changes, characteristic in the middle of the height of the samples (compare to Figure 2), while soaking, for all of seventeen soil compositions. After the 4-day saturation of the samples (Polski Komitet Normalizacyjny, 1998) the moisture of the soil on the side of the sample $\left(w_{2}\right)$ is higher than in the middle $\left(w_{7}\right)$. This phenomenon can be noticed at the remaining measuring points. The moisture of the soil at the side of the sample is clearly higher than in the middle, while the highest moisture content is obtained at the point $w_{3}$. It can be observed that moisture trend line characteristic to the axis of the sample $\left(w_{7}\right)$ and in the middle of it $\left(w_{4}\right)$ are close to each other, while the moisture content trend line characteristic to the side of the sample $\left(w_{2}\right)$ is clearly moved away. Although the moisture trend lines $\mathrm{w}_{4}$ and $\mathrm{w}_{7}$ are similar, it can be seen that in its middle the distance between them is the highest. That confirms the thesis regarding the impeded flow of water in the tested soils with the average fine fraction content.

The comparison of the moisture changes in the tested soil samples before and after the penetration test, allows for the conclusions that the moisture content at the edge of the soil sample $\left(w_{2}\right)$ is significantly reduced in the case of soils with smaller fine fraction contents. Along with the increase of amount of the fine fraction, the moisture content $w_{7} C B R$ measured after the penetration test ceases to decrease and for the fine fraction content greater than $15 \%\left(f_{\pi}+f_{i}>15 \%\right)$ the moisture content starts to increase. The comparison of the moisture content in the middle of the soil sample $\left(w_{7}\right)$ before and after the penetration test shows that this phenomenon is the most evident for the average fine fraction content - see Figure 14.

Figure 15 shows the dependence between an average displacement of annular surcharge ring and the indentation of the piston during the penetration test $v_{C B R}$. The comparison of the volume of pressed piston and the increase of the volume of the soil sample shows that during the penetration above $7.5 \mathrm{~mm}$, the volume of the piston is about twice as small. This indicates, that the volume of the soil sample during the CBR test increases, thus the soil 


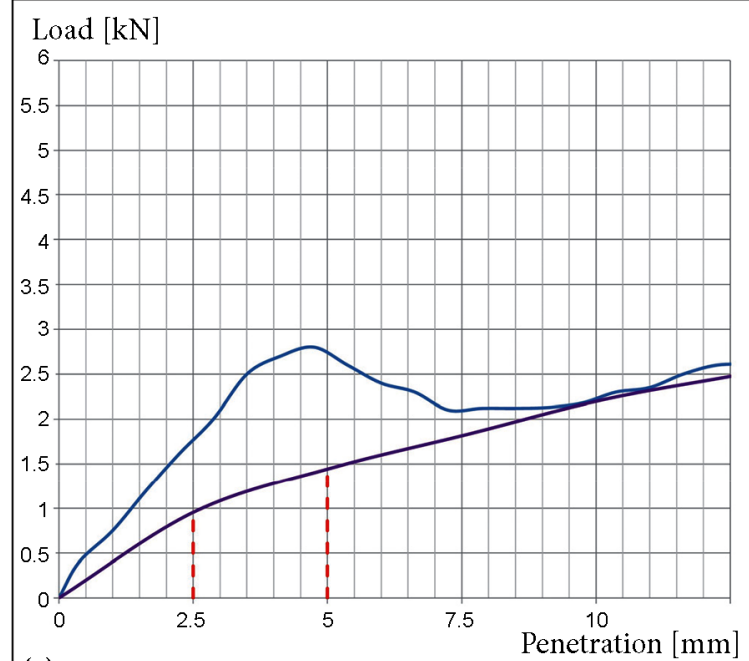

(a)

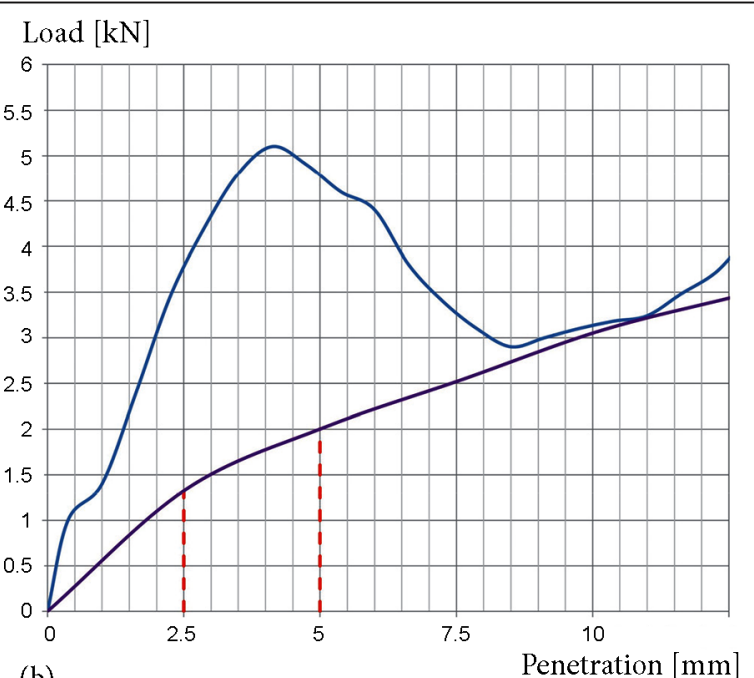

(b)

Figure 12. Corrected penetration graphs of soil samples (a) fine fraction content: $5.7 \%$ (b) fine fraction content: $12.0 \%$

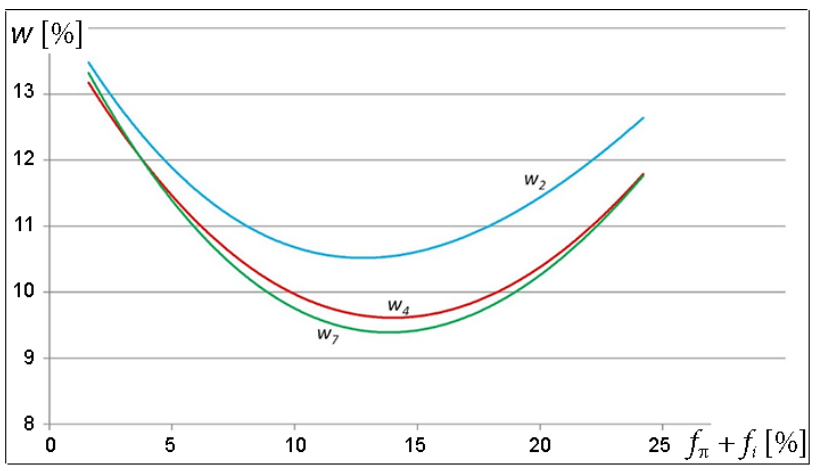

Figure 13. The dependence between the changes of the moisture trend line in the middle of the soil sample and the fine fraction content

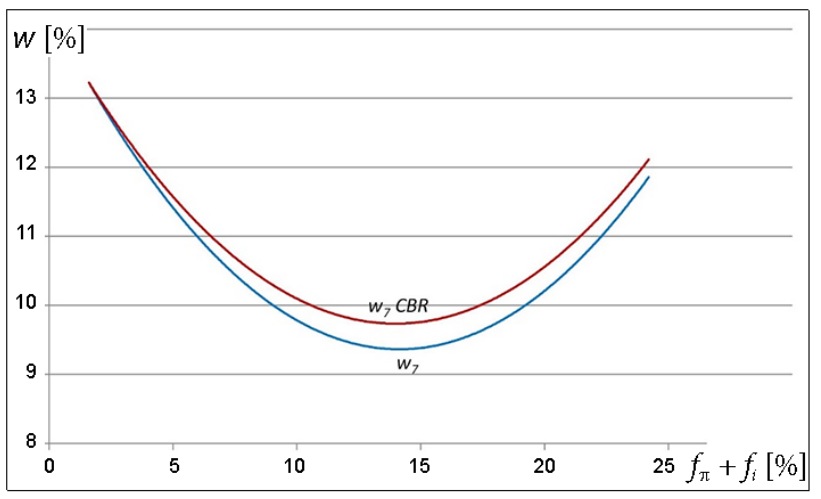

Figure 14. The changes of the moisture trend line in the middle of the soil sample before and after the CBR test with regard to the fine fraction content

loosening is observed. This phenomenon is the result of the water flow inside the soil sample (Roy, 2013; Habasimibi \& Nishimura, 2018). In all of the testes soil samples, regardless of the fine fraction content, a significant increase of the moisture content at points number 9 and 10 (com-

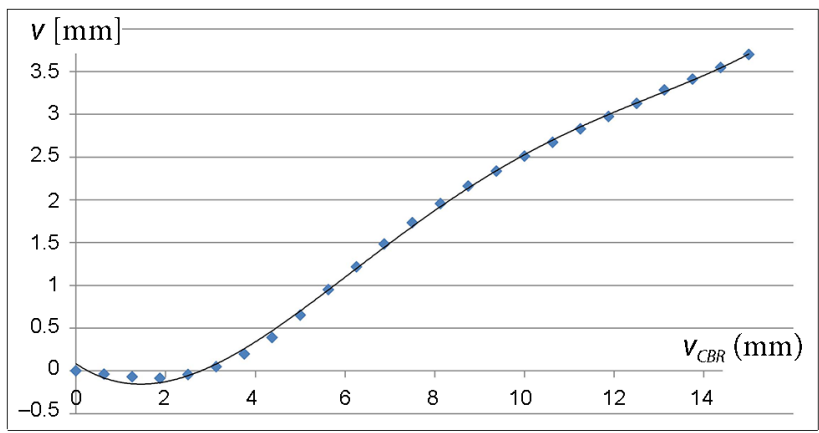

Figure 15. The dependence between the indentation of the press piston $v_{C B R}$ and the displacement of annular surcharge rings $v$

pare to Figure 2) were notable. This indicated the upward water flow during the penetration into the soil.

\section{Conclusions}

The detailed analysis of compactibility and CBR values was performed for soils classified as low-frost-susceptible soils. The soil samples were composed to obtain various fine fraction content. It can be noticed that the maximum dry density and optimum moisture content obtained in the Proctor Compaction test are changing in non-linear way along with the changes of the fine fraction content. Laboratory tests of the CBR value showed that tested soils, as opposed to the other soil subjected to the CBR test do not exhibit classic load capacity characteristics. This applies to the shape of the load - penetration curve in particular. It is clearly visible that the penetration curve deviates from the standard curve shape at various depths. Curve correction with the fourth degree polynomial was used to interpret the CBR value. It was also claimed that interpretation of the results according to the PN-EN standards (Polski Komitet Normalizacyjny, 1998, 2012, 2017) may involve 
the risk of large errors. According to the point 10.1.3, if the curve is concave upwards, it is recommended to correct with tangent to the point of inflection, as it is presented in Figure 1 of mentioned standards. Nevertheless, the curve may have a break in the initial section, which usually can be an apparatus error or the effect of surface irregularities. Additionally it should be noted that carrying out measurement to penetration depth of $12.5 \mathrm{~mm}$ is advisable due to the possibility of more accurate correction of obtained CBR values. Corrected CBR value increases along with the increase of fine fraction content $\left(f_{\pi}+f_{i}\right)$. This dependence can be described by the linear equation. Therefore, in research presented in this paper, the penetrations test was carried out to a depth of $15.0 \mathrm{~mm}$.

In further studies of low-frost-susceptible soils, an additional sensor to measure pressure changes during the penetration test will be installed. These tests are aimed to find dependence between the measured pressure value and the moisture in the sample cross-section.

\section{Author contributions}

The background research for this publication was carried out by all authors. R.C. conceived and designed the experiments. All authors performed the experiments, participated in the analysis of experiments results and wrote this manuscript.

\section{Disclosure statement}

Authors declare that they have no financial, professional, personal interest or benefit relate to the research described in this paper.

\section{References}

ASTM International. (2007). Designation D1883-07, Standard test method for CBR (California bearing ratio) of laboratorycompacted soils.

Bednarek, Ł., \& Mazurek, J. (2011). Ocena wpływu domieszek do kruszywa $0-63 \mathrm{~mm}$ na poprawę jego wskaźników nośności na podstawie wyników badań własnych. Górnictwo $i$ Geoinżynieria, 35(2), 89-94 (in Polish).

Cabalar, A. F., \& Mustafa, W. S. (2017). Behaviour of sand - clay mixtures for road pavement subgrade. International Journal of Pavement Engineering, 18(8), 714-726. https://doi.org/10.1080/10298436.2015.1121782

Chmielewski, R., \& Waliszewski, D. (2016). Wpływ ciężaru warstw konstrukcyjnych nawierzchni na wartość wskaźnika nośności CBR. Acta Scientarium Polonorum. Architektura, 15(2), 45-54 (in Polish).

Fattah, M. Y., Joni, H. H., \& Al-Dulaimy, A. S. A. (2016). Compaction and collapse characteristics of dune sand stabilized with lime - silica fume mix. Earth Sciences Research Journal, 20(2), I1-I8. https://doi.org/10.15446/esrj.v20n2.50724

Gadzama, E. W., Yohanna, P., Wadai, I. D., Nwaiwu, C., \& Malachy, O. (2018). Evaluation of compaction properties of some semi - arid zone soils. Leonardo Electronic Journal of Practices and Technologies, 17(32), 149-172.
Generalny Dyrektor Dróg Krajowych. (2014). Załącznik do zarzadzenia $n r$ 31. Katalog typowych konstrukcji nawierzchni podatnych oraz półsztywnych (in Polish).

Gonzalez, C., Barker, W., \& Bianchini, A. (2012). Reformulation of the CBR procedure. US Army Corps of Engineers.

Gupta, R. C., \& Thomas, B. S. (2013). A study on the optimum moisture content and maximum dry density of sandy and clayey soil stabilized by copper tailings. RCEE Research in Civil and Environmental Engineering, 1, 123-138.

Habasimibi, P., \& Nishimura, T. (2018). Comparison of soilwater characteristic curves in one-dimensional and isotropic stress conditions. Soil Systems, 2(3), 43.

https://doi.org/10.3390/soilsystems2030053

Hossain, A., Islam, S., \& Rakib, A. A. (2016). Use of coal mine dust as an improved subgrade material in road construction. American Journal of Environmental and Resource Economics, 1(1), 9-23.

Katte, V. Y., Mfoyet, S. M., Manefouet, B., Wouatong, A. S. L., \& Bezeng, L. A. (2019). Correlation of California bearing ratio (CBR) value with soil properties of road subgrade soil. Geotechnical and Geological Engineering, 37(1), 217-234. https://doi.org/10.1007/s10706-018-0604-X

Khillare, P. S., Damgir, R. M., \& Hake, S. L. (2016). CBR determination on subgrade soil by replacement of additives. International Journal of New Innovations in Engineering and Technology, 6(1), 49-54.

Kodikara, J., Islam, T., \& Sountharajah, A. (2018). Review of soil compaction: History and recent developments. Transportation Geotechnics, 17, 24-34.

https://doi.org/10.1016/j.trgeo.2018.09.006

Matsumura, S., \& Tatsuoka, F. (2018). Effect of compaction conditions and fines content on cyclic undrained strength of saturated soils. Soil Dynamics and Earthquake Engineering, 112, 152-161. https://doi.org/10.1016/j.soildyn.2018.04.029

Osouli, A., Chaulagai, R., Tutumluer, E., \& Shoup, H. (2019). Strength characteristics of crushed gravel and limestone aggregates with up to $12 \%$ plastic fines evaluated for pavement base/subbase applications. Transportation Geotechnics, 18, 2538. https://doi.org/10.1016/j.trgeo.2018.10.004

Osouli, A., Othmanawny, G., Tutumluer, E., Beshears, S., \& Shoup, H. (2018). Soaking effects on strength characteristics of crushed gravel and limestone unbound aggregates. Transportation Research Record: Journal of the Transportation Research Board, 2672(52), 34-45. https://doi.org/10.1177/0361198118756886

Osouli, A., Salam, S., Tutumluer, E., \& Shoup, H. (2017). Fines inclusion in a crushed limestone unbound aggregates base course material with 25.4-mm maximum particle size. Transportation Geotechnics, 10, 96-108. https://doi.org/10.1016/j.trgeo.2017.02.001

Pilegis, M., Gardner, D., \& Lark, R. (2016). An investigation into the use of manufactured sand as a $100 \%$ replacement for fine aggregate in concrete. Materials, 9(6), 440. https://doi.org/10.3390/ma9060440

Polski Komitet Normalizacyjny. (1998). Drogi samochodowe. Roboty ziemne. Wymagania i badania (PN-S-02205:1998) (in Polish).

Polski Komitet Normalizacyjny. (2012). Mieszanki związane $i$ niezwiązanie spoiwem hydraulicznym. Czesść 47: Metoda badania kalifornijskiego wskaźnika nośności, natychmiastowego wskaźnika nośności i pęcznienia liniowego (PN-EN 13286-47: 2012 (E)) (in Polish). 
Polski Komitet Normalizacyjny. (2017). Mieszanki zwiazane i niezwiązanie spoiwem hydraulicznym. Część 47: Metoda badania kalifornijskiego wskaźnika nośności, natychmiastowego wskaźnika nośności i pęcznienia liniowego (PN-EN 1328647: 2007) (in Polish)

Roy, T. K. (2013). Influence of sand on strength characteristics of cohesive soil for using as subgrade of road. Procedia - Social and Behavioral Sciences, 104, 218-224. https://doi.org/10.1016/j.sbspro.2013.11.114

Rozporządzenie Ministra Transportu i Gospodarki Morskiej. (1999). Rozporzadzenie Ministra Transportu i Gospodarki Morskiej z 2 marca 1999 r. (Dz. U. 43 poz. 430) W sprawie warunków technicznych, jakim powinny odpowiadać drogi publiczne i ich usytuowanie (in Polish).

Salam, S., Osouli, A., \& Tutumluer, E. (2018). Crushed limestone aggregate strength influenced by gradation, fines content, and dust ratio. Journal of Transportation: Part B: Pavements, 144(1). https://doi.org/10.1061/JPEODX.0000032

Satyaveni, B., Sridevi, K., Sivanarayana, C., \& Prasad, D. S. (2018). A study on strength characteristics of baggasse ash and phospho gypsum treated marine clay. International Journal of Civil Engineering, 5(7), 11-16. https://doi.org/10.14445/23488352/IJCE-V5I7P103

Sreelekshmypillai, G., \& Vinod, P. (2017). Prediction of CBR value of fine grained soils at any rational compactive effort. International Journal of Geotechnical Engineering. https://doi.org/10.1080/19386362.2017.1374495
Sulewska, M. J., \& Tymosiak, D. (2018). Analysis of compaction parameters of the exemplary non-cohesive soil determined by Proctor methods and vibrating table tests. Annals of Warsaw University of Life Sciences - SGGW. Land Reclamation, 50(2), 99-108. https://doi.org/10.2478/sggw-2018-0008

Thakur, Y., \& Yadav, R. K. (2018). Effect of bentonite clay on compaction, CBR and shear behavior of narmada sand. International Research Journal of Engineering and Technology (IRJET), 5(3), 2087-2090.

Wright, S. P., Walden, P. J., Sangha, C. M., \& Langdon, N. J. (1996). Observations on soil permeability, moulding moisture content and dry density relationships. Quartely Journal of Engineering Geology, 29, 249-255. https://doi.org/10.1144/GSL.QJEGH.1996.029.P3.08

Yin, C., Zhang, W., Jiang, X., \& Huang, Z. (2018). Effect of initial water content on microstructure and mechanical properties of lean clay soil stabilized by compound calcium-based stabilizer. Materials, 11(10). https://doi.org/10.3390/ma11101933

Zhemchuzhnikov, A., Ghavami, K., \& Casagrande, M. (2016). Static compaction of soils with varying clay content. Key Engineering Materials, 668, 238-246.

https://doi.org/10.4028/www.scientific.net/KEM.668.238 